\title{
THE DIFFICULT WAY OF SOCIAL PSYCHOLOGY IN RUSSIA
}

\author{
Galina M. Andreeva \\ Lomonosov Moscow State University \\ Moscow
}

The article describes the main stages and directions of the development of social psychology in USSR and Russia. The comparison of theoretical approaches of Russian and Western social psychology is carried out. Special emphasis is made on the problem of social cognition and coping, which are important in the conditions of changing reality. New professional tasks of social psychology are discussed. The necessity of finding a new paradigm in social psychological investigations in conditions of cardinal transformations and ambiguity is stated as well as vectors and tendencies of its elaboration.

Keywords: social psychology in USSR, social psychology in Russia, theoretical and methodological background, social changes, new paradigm.

This paper is dedicated to the characteristics of the complicated destiny of social psychology in Russia, something that Western colleagues may be aware of to some degree, but also may be subject to misapprehensions or myths. One of these myths is connected with the belief that there exists a special "Russian" (earlier "Soviet"). When psychology is discussed in regional terms specific countries appear in the scientific literature quite seldom, usually referring only to the "American" social psychology in the case of juxtaposition with "European". Meanwhile the attributions "German", "English" or "Swedish" seem not to be used in any cases (an exception concerns only "French" social psychology because of the fact that many researchers are engaged in some particular theoretical position). So first of all one has to explain the real specificity of social psychology in Russia. For these reasons (and not only because of national mentality) the narration will be rather long, in order to include some historical facts as well as a brief observations of the theoretical and methodological backgrounds. It would be quite difficult to explain the contemporary status of the discipline without that. 


\section{The main "landmarks" of the rise}

\section{and development of social psychology in Russia}

In fact it is rather impossible to speak about a "unique" history of social psychology as an academic discipline in Russia before the revolution of 1917. The problems included later in the subject-matter of social psychology were primarily elaborated within sociology (Solovjev, 1874; Sorokin, 1914) or were included into ideological conceptions of social movements and accepted by different social forces. This is the reason that traditionally social psychology was "angagiert" (affected) by ideology.

As to the academic status, one of the first systematic uses of the term "collective (social) psychology" was suggested by the sociologist M. Kovalevsky in the lectures read by V. Bekhterev's proposition in the Psychoneurologic Institute in Petersburg (Kovalevsky, 1910). Other references to social psychology were also to be found in sociological or public literature (Petrashicky, 1908; Michailovsky, et al. 1906-1914), and then in psychological works. In this case the connection with social-political movements was expressed less strongly. The most prominent contribution within this tradition was made by V.M. Bechterev (Bechterev, 1903). He defined for the first time the subject-matter of social psychology ("collective reflexology") and described one of the most important mechanism of influence - suggestion - studied both at the individual and collective level. Bechterev also organized the first university course in sociology where the relationships between sociology and social psychology were embraced.

In summary, the development of the social-psychological ideas in pre-revolutional Russia occurred predominantly not within the psychology but within the wider spectrum of social sciences. And here one has to look for the roots of the transformation in the history of social psychology which took place after the revolution of 1917.

\section{Social Psychology in the USSR}

The history of Soviet social psychology witnessed two stages of discussion concerning the subject-matter of the discipline: the 1920s and the late 1950-early 1960s. Both of these stages are interesting both from a historical point of view and because they help better understand the place social psychology occupies in the system of scientific knowledge and provide for a more precise definition of its content.

In the 1920s, that is in the first years of Soviet power, the discussion was stimulated by two circumstances. On the one hand, life in the newly-formed social structures required a solution to the problems relevant to social psychology. On the other hand, socio-psychological knowledge came to the orbit of the acute ideological struggle of those years. The content of this struggle was connected with a demand of reconstructing of the whole system of social sciences on the philosophical base of Marxism.

G.I. Chelpanov was among those who protested against this perspective. So he proposed the division of psychology into two parts: social and general psychology. Social psychology, in his opinion, had to be evolved within the framework of Marxism, whereas general psychology should remain an empirical science, independent of Marxism or any other world outlook. This point of view signified a formal recognition of the right of social psychology to exist as a science at the cost, however, of depriving of rest of psychology from the Marxist philosophical basis (Chelpanov, 1924).

It is no surprise that Chelpanov's idea was unacceptable for those psychologists who shared the idea of reconstructing the philosophical foundation of all psychology, of including the whole of it into the system of Marxist knowledge. Objections to Chelpanov took on various forms. At first the idea was expressed that as long as psychology was interpreted from the point of view of Marxist philosophy, the whole of it had a social orientation, and there was no need to single out a special branch - social psychology. There were also another arguments but the result was the same: attempts to turn social psychology into a separate discipline (or at least a separate branch of psychology) stopped for a considerable stretch of time. The problems involved were successfully tackled, but along other lines (especially pedagogic), rather than by creation of independent social psychology. This period is referred to as the "break" in the development of social psychology, if this term is relative. Later, with the growth of ideological pressure on social sciences, social psychology shared the fate of genetics, cybernetics and some other sciences because it was portrayed as "bourgeois science", which has no place in the socialist society. 
The second stage of the discussion concerning the subject-matter of social psychology took place in the late 1950s and the early 1960s together with the political "thaw". Two circumstances started a new debate. First, the requirement of practical activity was expanding. Basic economic, social and political problems called for a more careful analysis of the psychological aspect of various manifestations of social life. The interaction between society and individual had to be investigated on the socio-psychological, as well as on the sociological level. Secondly, at the moment when these problems were given a significantly greater amount of attention, there occurred profound changes in psychology itself: it has turned into a mature discipline based on solid theoretical work and experimental research. The essential prerequisites were thus created for new discussion of the destiny, subject-matter, tasks, methods of social psychology as well as its place in the overall system of science. The discussion of these issues on a new level had become both urgent and possible. Two approaches were formulated around the dispute about the appropriate subject-matter of social psychology, and these approaches are near to "sociological social psychology" and "psychological social psychology" in contemporary language

Supporters of the first approach, enjoying prevalence among sociologists, understood social psychology as a science of "mass phenomena of the psyche" and saw the object of study as research of the psychology of large social groups, of the formation of public opinion, of collective behavior and so on. The supporters of the second approach, on the contrary, considered the individual as the main object of social psychology's research: the position of the individual in a small group, interpersonal relations, the processes of communication, interaction, interpersonal perception.

In addition, a third approach emerged, in the form of an attempt to synthesize the two. Social psychology was seen as a science involving the study both of mass mental processes and the position of the individual in a group. In this case problems of social psychology seemed to be rather broad: one can see that practically the entire set of questions examined in both psychological and sociological social psychologies was included in its domain.

In spite of the fact that both the sociologists and psychologists took part in the discussion unanimously agreed that "social psychology has right to exist", its revival actually began within psychology, because here the danger of "ideological mistakes" was weaker and the status of psychology in society as a whole became rather secure. Sociology itself made only the first steps at that time. The first laboratories and departments were created in the institutes of psychology and consequently psychological social psychology was the first to be supported.

Thus one can speak about the "beginning" of the history of social psychology in the USSR only at the boundary between the 1950s and 1960s. The falling behind in the first half of the 20thcentury (if we start the history of Russian social psychology from 1908) explains many facts in the following development and status of the Russian social psychology.

\section{Theoretical and methodological background}

Having received the right for independent status, social psychology demonstrated two relatively independent directions of the development. First, there began active research of its own problems, coinciding with traditional fields of investigation fixed in "two" social psychologies. Second, studies of problems accompanied by methodological discussion which tried to define the means and level of "including" Marxist philosophical principles into social psychological research.

As compared with more ideologically based sciences such as sociology and political science, in social psychology this Marxist orientation did not have the "hard science" character of psychology in general. The problem was not rooted in the straight application of Marxism to the interpretation of the social-psychological phenomena, but in the explanation of how Marxist philosophy influenced the social-psychological theory. This "mediation" was proposed, as in general psychology, by L. Vygotsky's cultural-historical school and A. Leontyev's (1975) and S. Rubinstein's (1959) "theory of activity", based on the former.

Two famous hypotheses of Vygotsky are very important for the development of social psychology: the mediated character of humans' higher mental functions, and the origin of mental processes, basically "intermental" and later "intramental" (Vygotsky, 1983). These ideas led to the conclusion that the main mechanism of mental development was one of mastering the socio-historic forms of activity. Such an interpretation of the problems of general psychology provided a solid basis for the solution of the specific social psychological problems. 
As to the theory (or principle) of activity ${ }^{1}$, it has also very important meaning for social psychology. In psychology, activity is considered to be a certain subject-object relation where the individual as the subject relates in a definite way to the object as he or she masters it. In the course of activity, the individual realizes his or her interest by modifying the object-related world and satisfying his or her needs. New needs also arise through activity. Therefore, activity represents a process, in which human personality develops itself. Social psychology adapts the principle of activity with reference to the basic object of its research - the group. Therefore, the content of the principle of activity is contained here in following propositions: a) activity is understood as a joint social activity of people during which particular connections arise, for example, communicative connections; b) not only the individual but also the group acts as the subject of activity, introducing the idea of the collective subject of activity; this permits the investigation of real social groups as definite system of activity; c) it is not permissible to reduce group research only to empirical description, to the simple statement of individual actions outside the social context - the given system of social relations (Andreeva, 1979).

The application of these ideas to the investigations in social psychology was made by A. Petrovsky in his "Theory of activity mediation of the processes in small group", describing the process of group development. The fundamental concept of this idea is the new view of combined group activity as the determinant of all group processes, that is, its inclusion as the most important variable in the analysis of interpersonal relations in the group, of cognitive formations and so on. Especially important here is the idea that the development of the group can de viewed as a proportionately more and more complete mediation of the combined activity of all group processes. The concept "levels of group development" is introduced into the conception, and methods of diagnosis of these levels are devised (Petrovsky, 1979).

1 There is a well-known terminological difficulty in the interpretation of the principle of activity, connected with the fact that the word "activity" in a number of languages (Russian included) means both "activities" and "activeness". In Marx's works, written in German, there are two terms used: "Taetigkeit" and "Aktivitaet", with "Taetigkeit" used in the meaning implied here. In English "activity" covers both meanings.
The adoption of the principle of activity stipulated the logic of the subject-matter of social psychology. The whole construction looks approximately as follows. Because communication and interaction between people take place not in a vacuum but always in already existing society (this being the first empirical fact for researcher), the first part of social psychology - "communication and interaction" - should start with the analysis of the place that these phenomena occupy in the structure of social relations.

Here I have to make another terminological commentary, because the using of the word "communication" has special meaning in Russian psychological language. We speak practically about "communication" not in the narrow sense but in its broadest sense - as the reality of social and interpersonal relations, as the "realization" of these relations. So we try to connect this process with activity and include communication immediately in social context. We introduce for this goal the new notion "obshcheniye" and this word has no English equivalent. Some of colleagues proposed to translate this word as "intercourse" or in German as "Verkehr", but I am not sure these are most nearly equivalent. I prefer to explain that "obshcheniye' include three processes: communication, interaction and social perception.

After the general characteristics of these socio-psychological processes have been revealed, it becomes necessary to analyze their modifications in various social groups - first of all, "large" and then, "small". Therefore, Social psychology of groups can logically be considered the second part of social psychology. The final stage is analysis pertaining to the ways in which social group determines behavior and actions of the individual within it. Thus, the third logically defined part of socio-psychological knowledge is social psychology of the personality. Only within such a structure the personality can be "attached" to the social context.

The whole traditional subject-matter of social psychology can be organized within the limits of these parts. The fact that the above proposed logics gives the opportunity to form quite a holistic and systematic picture of the discipline constitutes the specifics of that approach. Some particular principles are immediately explicit: all the problems are considered within the social context; the individual subject's activity as well as the group subject's activity are acknowledged; the interpretation of the empirical data within one and the same theoretical scheme is ensured. 
So I tried to describe the content of Social Psychology in next blocks.

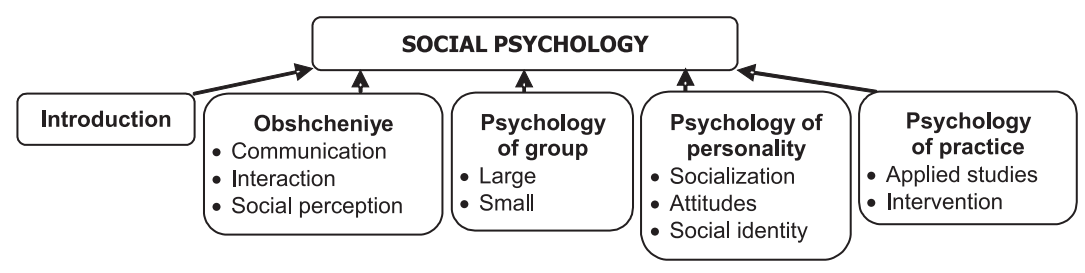

Along with the elaboration of its own approach to the content and structure of socio-psychological knowledge, Soviet social psychology was actively mastering the western socio-psychological experience. This was the sphere mostly influenced by ideology. Recurrences of radical negative attitude towards the Western tradition - the attitude typical for the 30s - 50s when social psychology was merely denied - were still present in some publications dated back to the period of its revival. The attitude was manifested in the statement that all Western conceptions and studies were the products of Bourgeois science and so criticism of principle should be the only possible way to relate to it. Often this attitude was in contradiction with practical application of many Western empirical and theoretical results.

During the time of political "thaw" the position was shaped differently. There appeared some works that provided a more objective account of popular Western thought but there still remained some criticism concerning positivist epistemology (Andreeva, Bogomolova, Petrovskaja, 1978; Shichirev, 1979; Shichirev, 1985). The existence of controversy within American and European social psychology meant that the debate moved from being an ideological dispute and turned into scientific discussion.

The fact that a number of Soviet scientists entered the European Association of Experimental Social Psychology as well as establishing personal contacts with western colleagues stimulated the integration of Russian social psychology into the context of the world science, so that many typical problems of $60 \mathrm{~s}-70 \mathrm{~s}$ seem to be difficult to understand today. ${ }^{2}$

2 In this connection I can't help remembering gratitude H.Tajfel who did all his best for involvement of Russian scientists into the world scientific community.
Meanwhile some problems still exist within the dialogue with the Western tradition. The main problem concerns some kind of "inequality" in sharing information. The works of American and European authors were rather well known even in the USSR and even more so in Russia. A majority of professionals read them in English, but also many books and articles are now translated into Russian. Unfortunately Russian work is very seldom published in the West, and as a rule such work appears as separate articles. The only source of information for Western colleagues are personal contacts or occasional presentations of Russian scientists at the international congresses, conferences and symposia. It is clear that these difficulties are based in the problem of language as well as in some other problems.

The reason, as I see it, deals with the consequences of the fact that Soviet science was being isolated for a long time from the western scientific community. Obviously this isolation mainly concerns the social sciences. The lack of awareness about Russian work also reflects the fact that regular scientific contacts have only been happening quite recently. So many new ideas and results of studies are not yet spread in West. ${ }^{3}$ One can find many examples in which, when acute problems of contemporary polemics have been discussed among Russian colleagues long before, but were unknown in the West. All these facts are of great importance today, when the problems of the construction of the new paradigm in social psychology are discussed in the literature.

The idea of uniting "two" (or may be "three") social psychologies was presented to Russian colleagues long ago - in the late 50s - during the discussion of the destiny of social psychology in Soviet society. As mentioned above, the structure of the subject-matter of the discipline itself was interpreted from the very beginning as including both psychological and sociological aspects. The need to take into account the social context in every experimental study was absolutely natural because

\footnotetext{
It would be interesting to conduct an experiment in western colleagues were asked to think of the names of ten Russian social psychologists working in the field of communication, interpersonal perception, group dynamics, leadership, attitudes, socialization, intergroup relations, conflict, ethnopsychology, organizational behaviour, etc. At the same time, I invite any of the members of EAESP to put analogous questions to my students and ask them to name the authors of theories of social attribution, social influence, frustration-aggression, social comparison, cognitive dissonance, dyadic interaction, social identity, social representations, phenomenon "group- think" or constructionism.
} 
the interpretation of empirical data used to include the social factors of its determination. For example: the problem which is cold to-day the problem of "social attribution" practically was solved many years ago in our study of the interpersonal perception and attribution by taking into consideration the fact that both the subject and the object of process were belonging to the group. In the first edition of the university textbook on social psychology (Andreeva, 1980; 1982) I proposed the scheme where 8 positions of studies of interpersonal perception and attribution were designe.

\section{SUBJECT OF PERCEPTION:}

PERSON

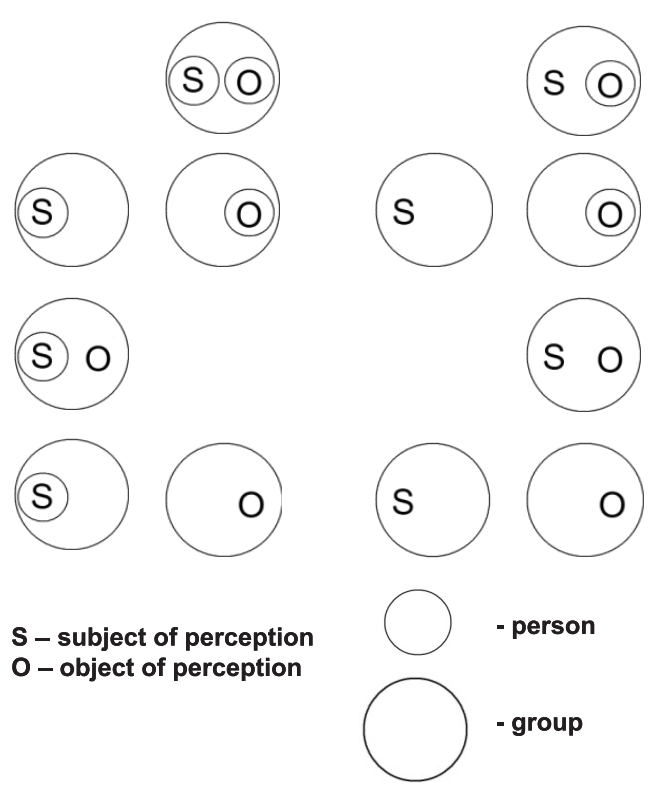

These and other directions of the analysis were dictated by initial methodological prerequisites described above. It helped to resist the positivist "expansion" and shoves the possibility not only to compare the positions of Russian social psychology with the European trends but also to find many common points.

\section{The Social Psychology in Russia to-day}

Nowadays most of those problems are in the focus of attention in contemporary discussions of the new horizons of social psychology among the world scientific community. Under these circumstances it is especially relevant to develop further cooperation with European colleagues that gives both traditions the opportunity to represent their arguments and strengthen research. More information, specifically about Russian social-psychological research and the new status of social psychology resulting from the transformations in this country is one of the preliminary conditions of this discussion.

The issues discussed in this paper are closely connected with one more point concerning social psychology's social potential, its role in the epoch of rapid social changes, and its theoretical and practical perspectives on $21^{\text {st }}$ century society. From this point of view the Russian experience can be very interesting to western readers: in spite of the fact that some relevant studies were partly published in the international editions, the whole picture of contemporary Russian realities is hardly known in the world.

The postcommunist Russia could serve a good illustration for existing society in the situation of rapid and radical transformations in all branches of social life. The central point of investigations for social psychology in such conditions is the analysis of the new paradigm in contemporary social psychology. As vectors of it are considered: strengthing of a social context's role in researches, accent on the analysis of the social change, specific aspects of social cognition (cognition of new social world by "ordinary" men for coping with changes). So the problems of "Social Cognition" are coming ahead on both - theoretical and practical - levels. I belief the previous development and potentials of "activity paradigm" hade good base for fulfilling this task: many topics of previous studies are immediately close to new problems: social categorization, social perception, attribution process, intergroup relations and intergroup perception, the coping, the "turn to the language", social identity in conditions of globalization at al.

The situation in Russia is characterised by break of stereotypes, by changing of the hierarchy of values, by crisis of identity. The long period of changes has a result the formation of the new social stratums, the growth of social inequality and other very important events in social 
life. It means the difficulties for mass consciousness to orient in the new world. The process of adoption became the new traits. The main studies of last period are connected with these topics as well as with new models of organizations of social life (Shuravlev, 2004).

One of the main point in the new situation is creating of methodology for study the unstable social world, because the all history of social psychology was connected with stable society and all research methods were adopted to describe and to explain these kind of events. So many new professional tasks arise for social psychology in the instable situation in society. It concerns for example some problems of methodology. One of very popular method - questionnaires - must be revised because the terminology used in them does not correspond to new language of society: many words lost their meaning ("collective property", "socialis competition"), the other change or get contradict content for different social groups ("communist", "democrat", "private ownership").

More global problem is connected with the role of social psychology in the society - the relationships between them in the conditions of globalization. It is obvious that social psychology has a duty to get to people more information about patterns of behaviour in different societies, to describe more alternative models of actions, to propose the methods of communication not only between different ethnic groups but also between other different social groups, for example between those who are "winners" and "losers" after social transformations. This kind of recommendation can be very useful for a changing men in changing society.

The situation in the transitional society looks like the situation in the conditions of the "cultural shock" when a person perceives himself as in a strange country: everything is unusual and unknown. All the social institutions change their image: family, school, church, mass media. The new type of social reality demands the new solutions of many social psychological problems, especially in the field of social cognition (the difficulties of social categorization, the growth of perceptual and cognitive "errors", the need of rapid decisions in indefinite situations...), first of all - the construction of the new image of social world. It means that the search of new paradigm in social psychology becomes a practical task in Russia to-day. Many directions of empirical researches are conducted during last years within the proposed approach (Andreeva and Donzov, 2002). Unfortunately, as I noticed earlier, the content of them are unknown to European colleagues. The main methodological question is - can the elaborated in Russian social psychology paradigm "activity paradigm" - pretend on the place within the new paradigm in world social psychology? It seems to me that I can give the affirmative answer.

The described problems demand to develop social psychology in new context both on the fundamental and applied levels. It is clear that the tasks standing for social psychology of 21-th age are very similar in many units of the Planet. May be it is very appropriate time to unite the forces of different theoretical conceptions in world social psychology for decision them. The process of globalization is especially important in the initiating of this process.

My goal is to proof the need of more cooperation between Russian and European traditions in social psychology taking into account both theoretical and methodological ideas of the two approaches which have many general points.

\section{References}

Andreeva, G.M. (1979). The development of Social Psychology in USSR. In L. Strickland (ed.). Soviet and Western Perspective in Social Psychology. London: Pergamon Press.

Andreeva, G.M. (1980; 1988; 1994; 1996; 1998; 2000; 2005; 2008). Socialnaja psykhologija [Social Psychology]. Moskva: Aspect Press.

Andreeva, G.M. (1982). Common activity as a Factor of Causal Attribution in a Small Group. In H. Hiebsch (ed.). Social Psychology. XXII International Congress of Psychology. Berlin: VEB Deutscher Verlag der Wissenschaften.

Andreeva, G.M. (1984). Cognitive Processes in Developing Groups. In L. Strickland (eds.). Directions in Soviet Social Psychology. Springer-Verlag.

Andreeva, G.M. (1998; 2002; 2005). Psychologija socialnogo posnanija [Psychology of Social Cognition]. Moskva: Aspect Press.

Andreeva, G.M. (2001). Successes and Failures of Russian Social Psychology. European Bulletin of Social Psychology, 13, 3.

Andreeva, G.M., Bogomolova, N.N., and Petrovskaja, L.A. (1978; 2002). Sovremennaja socialnaja psykhologija na Zapade: theoreticheskije orientazii [Contemporary Social Psychology in the West: Theoretical Orientations]. Moskva: Aspect Press.

Andreeva, G.M., and Gosman, L.J. (1981). Interpersonal Relationships and Social Context Personal Relationships. In S. Duck, and R. Gilmour (eds.). Studing Personal Relationships, 1. Academic Press. 
Andreeva, G.M., and Donzov, A.I. (eds.) (2002). Socialnayaya psikhologia v sovremennom mire [Social Psychology in the contemporary world]. Moskva.

Beckterev, V.M. (1994). Kollektivnaja refleksologija [Collective Reflexology]. In V.M. Beckterev. Izbrannyje raboty po socialnoj psikhologii [The Selected Works on Social Psychology]. Moskva.

Chelpanov, G.I. (1924). Psikhologija i marksizm [Psychology and Marksizm]. Moskva.

Kovalevsky, M.M. (1910). Sociologija [Sociology]. Sankt-Peterburg.

Leontjev, A.N. (1975). Dejatelnost. Soznanije. Lichnost [Activity. Consciousness. Personality]. Moskva.

Michajlovsky, N.K. (1906-1914). Polnoe sobranie sochinenij [Complete works]. Sankt-Peterburg.

Petrazhickij, L.I. (1908). In M.A. Reisner (red.). Teoriya L.I. Petrazhickogo, marksizm i socialnaya ideologija [The Theory of L.I. Petrazhickij, The Marxizm and Social Ideology]. Sankt-Peterburg: Obshhestvennaya polza.

Petrovsky, A.V. (ed.) (1979). Psikhologicheskaja teorija kollektiva [Psychological Theory of Collective]. Moskva.

Rubinshtein, S.L. (1959). Prinzipy i puti razvitija psikhologii [Principles and ways of the development of psychology]. Moskva.

Shuravlev, A.L. (ed.) (2004). Problemy ekonomicheskoj psikhologii [Problems of Econonomical Psychology]. Moskva.

Shichirev, P.N. (1979). Sovremennaja socialnaja psikhologija SShA [Contemporary Social Psychology of the USA]. Moskva.

Shichirev, P.N. (1985). Sovremennaja socialnaja psikhologija v Zapadnoj Evrope [Contemporary Social Psychology in Western Europe]. Moskva.

Shichirev, P.N. (1999). Sovremennaja socialnaja psikhologija [Contemporary Social Psychology]. Moskva.

Solovjev, V.S. (1874). Pozitivism. Teorija Ogyusta Konta o trech fazach v umstvennom razvitii chelovechestva [Positivism. Theory of August Conte...]. Pravoslavnoje obozrenije, 2. Sankt-Peterburg.

Sorokin, P.A. (1914). Obzor teopij i osnovnykh problem progressa [Survey of Theories and main Problems of the Progress]. Noviye idei v sociologii, 3. Sankt-Peterburg.

Vygotskij, L.S. (1983). Istorija razvitija vysshikh psychicheskikh funkcziij [History of the Development of the High Mental Processes]. In Sobr. soch. v 6-ti t. T. 3. Moskva: Pedagogika. 